\title{
Waste Reduction in a Manufacturing Process: A Case Study of Ceramics Factory in Thailand
}

\author{
Puttasayan Narapinij \\ Department of Industrial Engineering, Faculty of Engineering, Rajamangala University of Technology Lanna, Chiang Mai 50300, \\ Thailand
}

\begin{abstract}
The objective of this research is to reduce waste in the production ceramics of Ceramics Factory in Thailand. The 7 Quality Control Tools (7 QC Tools) were implemented including Check sheet, Graph, Pareto diagram and Fishbone diagram, which were used to analyze and solve the problems. It was found that most of the wastes come from burning ceramics process. The kilns and trolleys has been used for a long time. Furthermore, the equipment and parts were damaged from lack of maintenance. The non-standard of product arrangement method into the kilns were the cause of waste. Thus, the researcher improved trolleys into the kilns and designed a fixture to help worker to product arrangement. The results of the research gathered data from quality inspection department. Then comparing data before the improvement (between September 2013 to December 2013) and after the improvement (between November 2014 to February 2015), the wastes are reduced from $8.97 \%$ to $0.29 \%$. The result of improving is very efficiency because it can reduce the wastes by $8.68 \%$.
\end{abstract}

Key words: Waste reduction, ceramics, 7 Quality Control Tools, continuous improvement.

\section{Introduction}

The manufacturing industry plays an important role in the national economy. A large portion of the investors have favored Thailand as a production base. However, the competition in the ceramics industry currently has been so stiff that many firms shut down with the different reasons. The falling competitiveness, the economic fluctuations, the instability of exchange rates, the hike of the fuel oil, as well as the threat of political turmoil, all these are considered potential factors that have affected the economic growth of the country and the productions as whole. Thus, in order to optimize the competitiveness, it is important for the corporate executives to give a considerable attention to improve the production process and maximize the performance. When the disposal of the potential numerous wastes generated in the production process, the plants that affects the higher cost of production than it ought to be [1]. In the case factory, the preliminary

Corresponding author: Puttasayan Narapinij, Ph.D., research fields: production planning and control. analysis of the problems is performed and assessment is implemented by interviewing the operators in management position. The problems are identified in pre-burn and post-burn process, which several mistakes are identified to the workers who lack the comprehensive knowledge and deficiency in a serious improvement. The assessments shows that the case factory experiencing the problems on productivity improvement, the workers lack of skills and knowledge, adversely affecting production efficiency, leading to the mass waste.

As mentioned above, the quality control is needed to the production process to minimize the waste generated in the production process. The waste problems have an impact on the factory and the serious problem-solving not been paid an attention. At present, the case factory reports non-compliance performance, none definite solutions and none analysis of the waste generated in the production process. Thus, the researcher has the interest to investigate and find out how to minimize the waste in the manufacturing process. The development of the 
product quality by using the $7 \mathrm{QC}$ Tools include the Check sheet, Graphs, Pareto chart and Fishbone diagramas instrument to analyze the underlying causes $[2,3]$. Therefore, these two solutions identify to improve the quality of product and optimize the production process for such a plant.

\section{Methods}

Methodologically, the Quality Control Circle (QCC) is developed with the use of the Plan, Do, Check, Action (PDCA) circle to plan for the waste solution, targeting to reduce waste by at minimal 5\% [4-6]. The research method is shown in Fig. 1.

\subsection{Examine Production Process}

Fig. 2 shows ceramics production process.

\subsection{Collect Data on Waste in the Production Process}

The data before improvementon productivity and

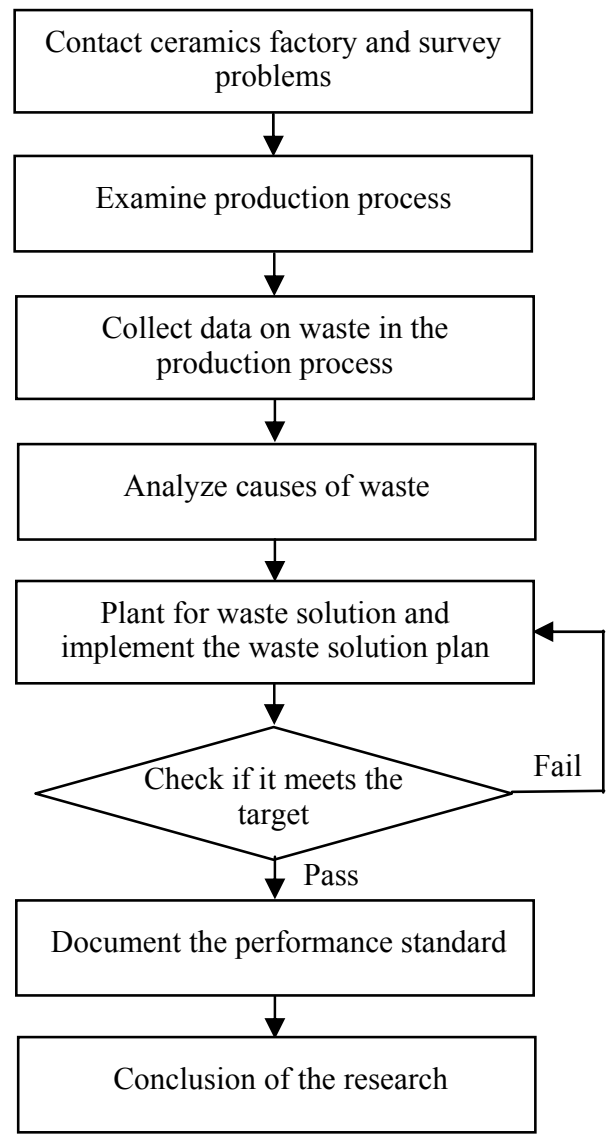

Fig. 1 Research method.

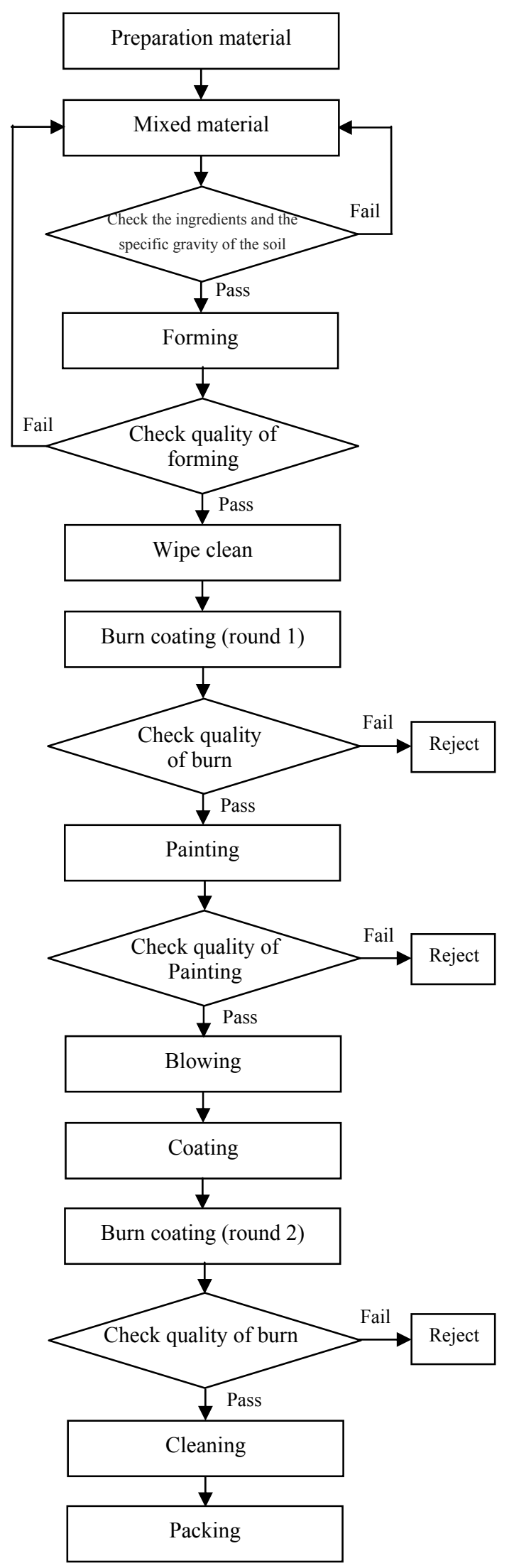

Fig. 2 Process of ceramics. 
the amount during September 2013-December 2013 are shown in Table 1. Table 2 shows the type of waste before improvement. Pareto chart of waste is shown in Fig. 3. The type of waste caused is shown in Figs. 4-7, respectively.

\subsection{Analyze the Causes of Waste Generated in} Production Process

The Pareto chart shown in Fig. 3 that waste caused by Chipping, representing 40.1\%, Pinhole 35.3\%, Crack $16.5 \%$ and Bubble $7.3 \%$ which is the main waste. Analysis of the causes of waste generated by the man, machine, material, method and environment

Table 1 The data before improvement.

\begin{tabular}{llll}
\hline Month/year & $\begin{array}{l}\text { Production } \\
\text { (pieces) }\end{array}$ & $\begin{array}{l}\text { Waste } \\
\text { (pieces) }\end{array}$ & Waste (\%) \\
\hline September/2013 & 1,086 & 196 & 18.04 \\
October/2013 & 1,392 & 132 & 9.48 \\
November/2013 & 2,404 & 213 & 8.86 \\
December/2013 & 2,794 & 148 & 5.29 \\
Total & 7,676 & 689 & 8.97 \\
\hline
\end{tabular}

Table 2 The type of waste.

\begin{tabular}{llc}
\hline Type of waste & $\begin{array}{l}\text { Waste } \\
\text { (pieces) }\end{array}$ & Waste (\%) \\
\hline Chipping & 276 & 40.0 \\
Pinhole & 243 & 35.3 \\
Crack & 114 & 16.5 \\
Bubble & 50 & 7.3 \\
Other & 6 & 0.9 \\
Total & 689 & 100.0 \\
\hline
\end{tabular}

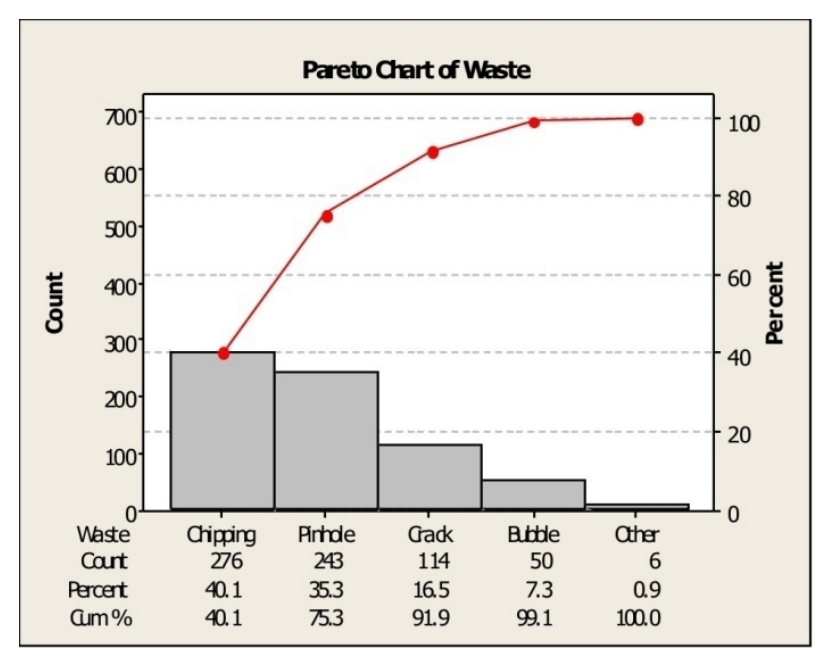

Fig. 3 Pareto chart of waste.

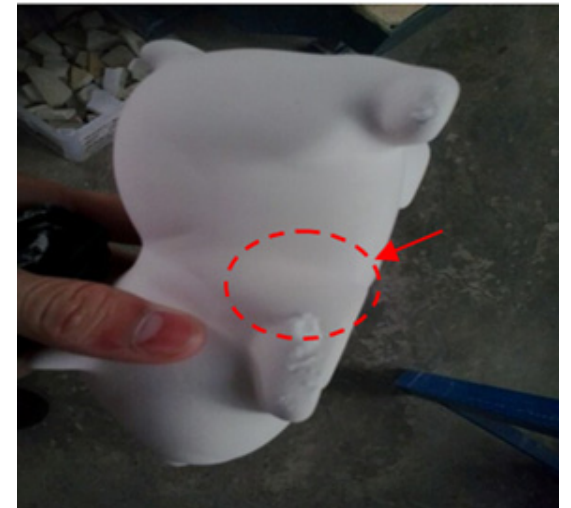

Fig. 4 Chipping of ceramics.

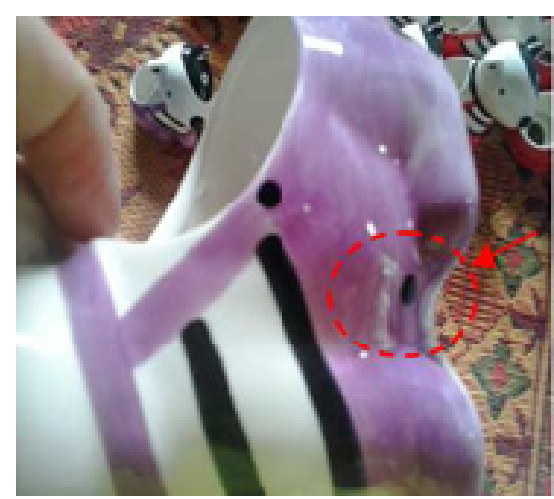

Fig. 5 Pinhole of ceramics.

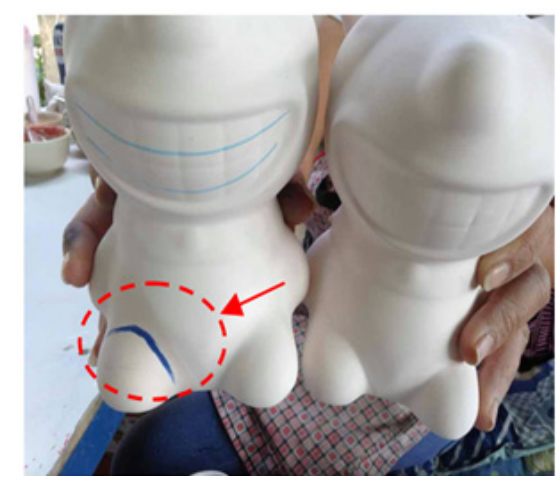

Fig. 6 Crack of ceramics.

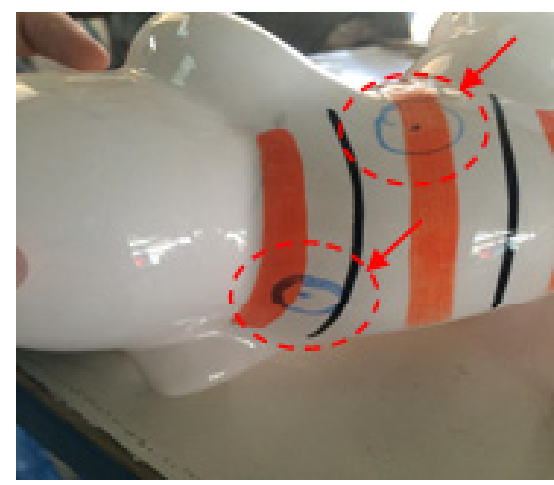

Fig. 7 Bubble ofceramics. 


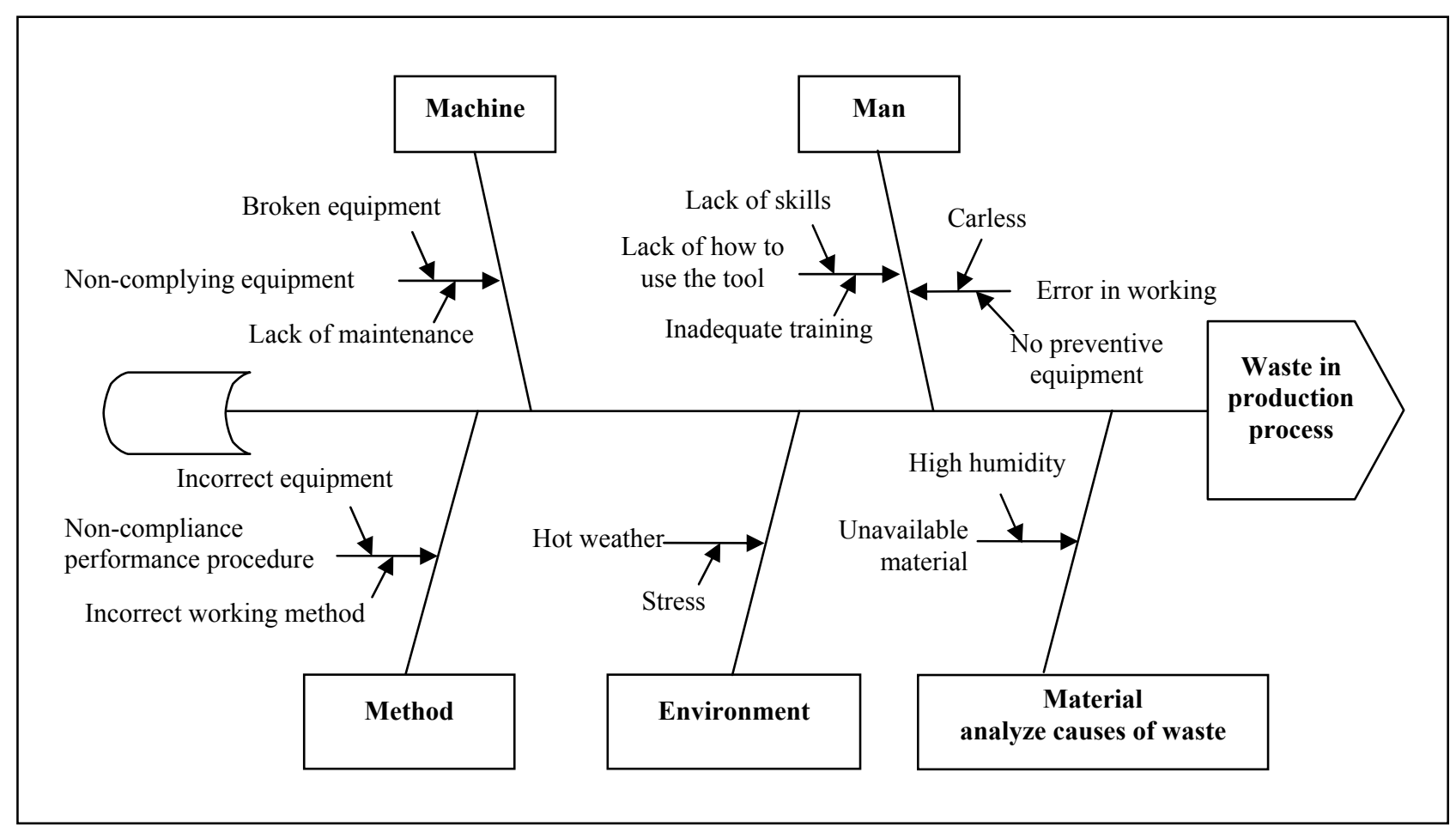

Fig. 8 Fishbone diagram.

Table 3 Causes and solutions.

\begin{tabular}{lll}
\hline No & Cause & Solutions \\
\hline 1 & Trolley is worn out & -Remove the broken fire bricks and replaced by the new ones on the trolley; \\
& & - Plated with the insulating fiber on the trolley; \\
& -Fix the trolley's wheel locks to prevent the trolley from moving to the kiln; \\
& & - Repair the fire brick oven on the chimney; \\
& Kiln is broken down & -Insulation of fiber inside the kiln; \\
& & -Replace a new lock cup; \\
& $\begin{array}{l}\text { Non-complying arrangement of the pieces } \\
\text { into the kiln by workers }\end{array}$ & -Design the fixture to ease rearrangement. \\
\hline
\end{tabular}

is conducted using the Fishbone diagram as shown in Fig. 8 [7].

\subsection{Plan for Waste Solutions}

To plan for waste solution, note that the waste that is caused by man, machine and method which can be manipulated while material is a factor that is unchangedable and the environment is a factor that is uncontrollable. The solution requires the E, C, R and $\mathrm{S}$ concept as shown in Table 3 [8-10]. A sequences of improvement includes:

(1) Researcher and business owner improve the trolleys to support the work pieces. Fig. 9a shows the before improvement trolleys. It's apparently cracked, the rapture of the brick is caused by deterioration of concrete without fiber insulation. Upon improvement as shown in Fig. 9b is covered by fiber insulation inserting between the raptured bricks to keep the heat constant;

(2) Fix the cracks of the fire bricks at the entrance of the kiln on the side wing of the kiln, and insulated with the insulating fiber inside the kilns, followed by improving the lock cups. Fig. 10a shows before improving the locks, the insulating fibers at the entrance of the kiln is deteriorated and dislocated. At improvement, the insulating fibers are cut in a bit larger 


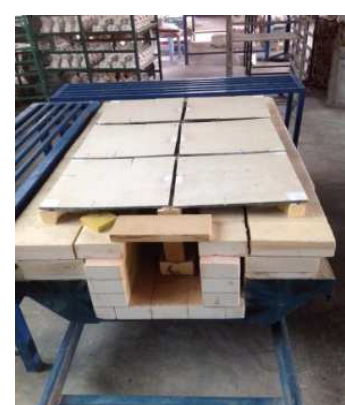

(a)

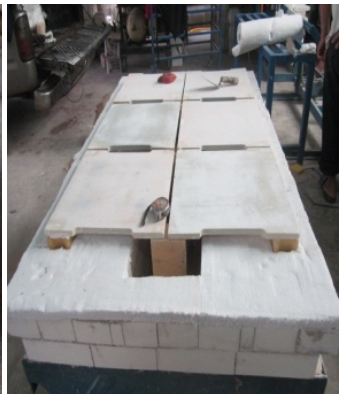

(b)
Fig. 9 Improve trolleys: (a) before and (b) after.

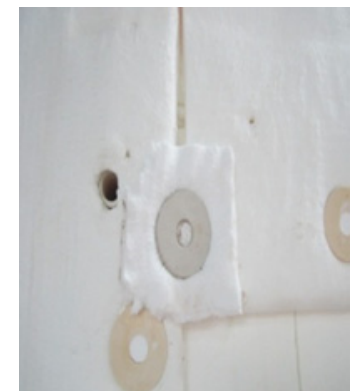

(a)

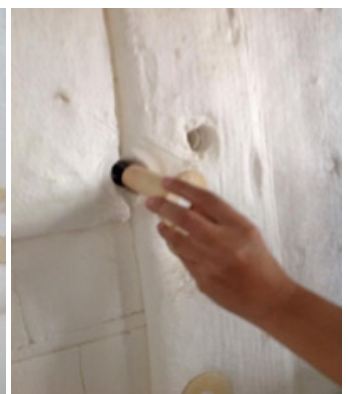

(b)
Fig. 10 Improve rock caps: (a) before and (b) after.

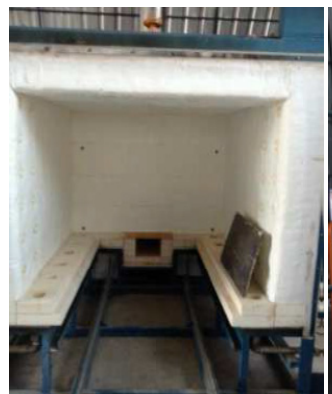

(a)

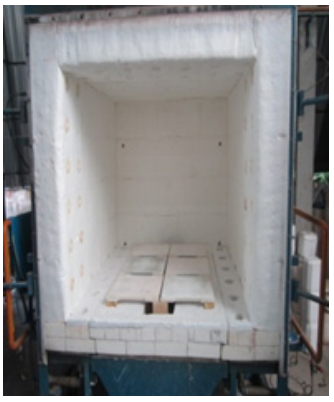

(b)
Fig. 11 Improve kilns: (a) before and (b) after.

size than ceramic lock cups, and take the prepared lock cups to compare with the cut fibers to tighten the door of the kiln firmly as shown in Fig. 10b.

In Fig. 11a, the old kilns that are not insulated with the fibers (Kiln is broken down). In Fig. 11b, it shows improve the kilns that are ready-to-use. It is insulation of fiber inside the kiln. After improving, the kilns inquiries are given, which evidenced that it consumes lesser fuel and lesser pressure, but more stable arrangement of the work pieces, the waste reduces consequently.

(3) Improvement process is rested in the E, C, R and S concept. E represents "Eliminate", C for "Combine",
R for "Rearrange" and S for "Simplify". Namely, the equipment is made in easy-to-use (simplify). In Fig. $12 \mathrm{a}$, non-complying arrangement of the pieces into the kiln is done by workers. Fig. 12b shows the operation of the designed fixture. The ceramic work pieces are filled into the cavity, and then remove the fixture while the work pieces are placed on pad material, with the cavity by the size of the fixture to keep the ceramics from exposure that may cause the waste. Fig. 13 shows the fixture that is adjustable as to the varying size of the work pieces.

\section{Results}

As shown in Table 4, the results show the production process and the amount of waste at after improvement. The waste is $0.35 \%$ in November 2014, $0.20 \%$ in December 2014, $0.21 \%$ in January 2015, $0.39 \%$ in February 2015 or representing $0.29 \%$ on average.

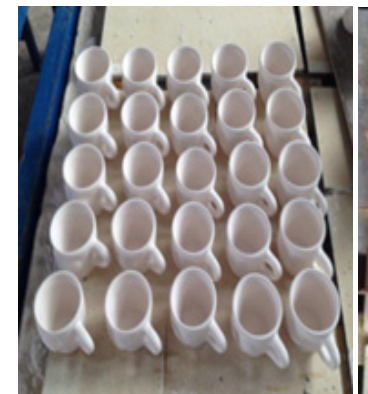

(a)

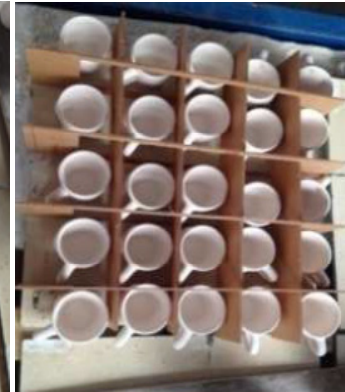

(b)
Fig. 12 Improve arrangement method: (a) before and (b) after.

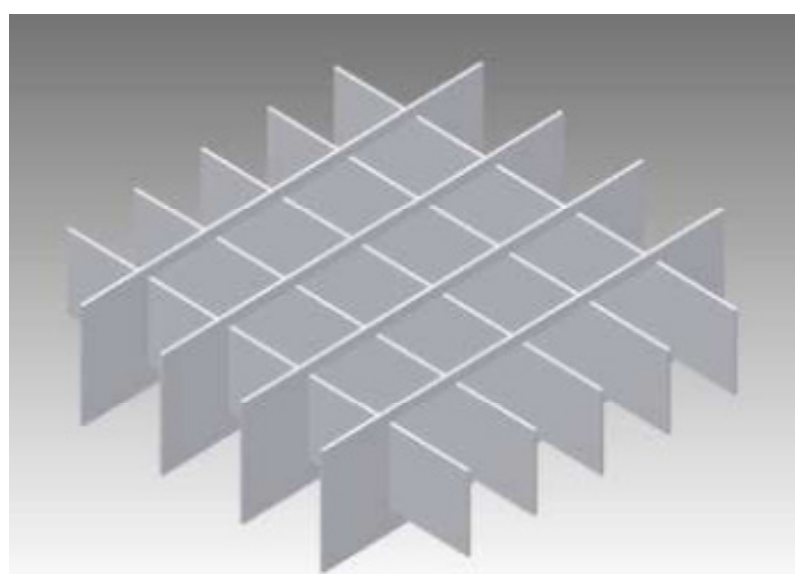

Fig. 13 The figure design. 
Table 4 The results of after improvement.

\begin{tabular}{llcl}
\hline Month/year & Production & Waste & Waste (\%) \\
\hline November/2014 & 14,593 & 51 & 0.35 \\
December/2014 & 13,895 & 28 & 0.20 \\
January/2015 & 10,982 & 23 & 0.21 \\
February/2015 & 13,580 & 53 & 0.39 \\
Total & 53,050 & 155 & 0.29 \\
\hline
\end{tabular}

Table 5 The comparison results (before and after).

\begin{tabular}{lll}
\hline Month/year & Waste & Waste (\%) \\
\hline $\begin{array}{l}\text { September/2013-December/2013 } \\
\text { (Before improvement) }\end{array}$ & 689 & 8.97 \\
$\begin{array}{l}\text { November/2014-February/2015 } \\
\text { (After improvement) }\end{array}$ & 155 & 0.29 \\
\hline
\end{tabular}

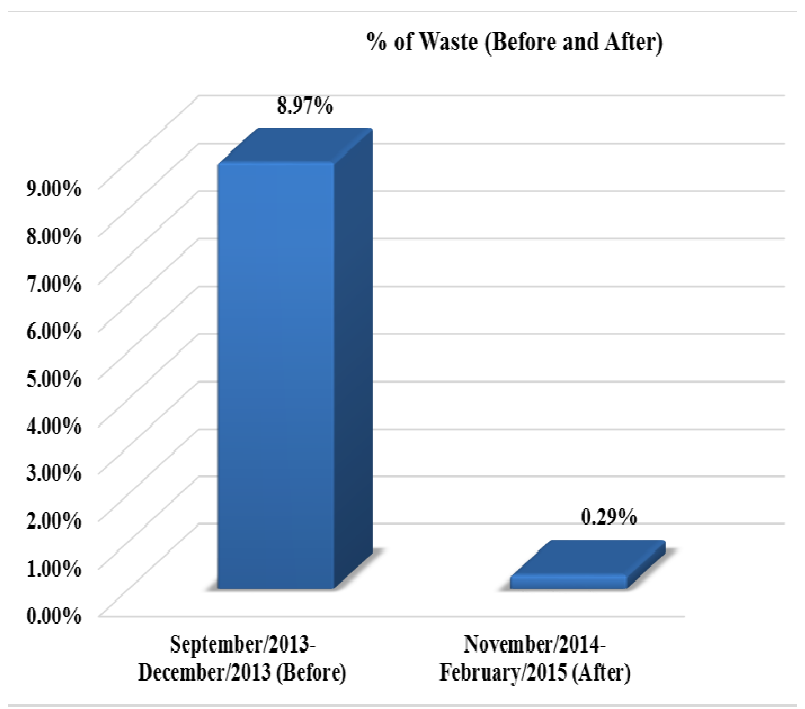

Fig. 14 Graphical percentage of waste.

Table 5 shows the comparison between before and after improvement. Four-month before improvement data (September 2013-December 2013) and 4-month after improvement data (November 2014-February 2015), the amount of waste generated from the manufacturing process for 689 pieces represented $8.97 \%$, decreased to 155 pieces or $0.29 \%$ as shown in Fig. 14. As a result, the waste generated from the manufacturing process decreased by $8.68 \%$.

\section{Conclusion}

In this study, the reduction of waste generated in the ceramics manufacturing process through the implementation of the QC Tool consisted of the Check sheet, Graphs, Pareto chart and Fishbone diagram is examined to analyze the causes and to identify the solutions. The results showed that waste problems mostly are caused by burning the ceramic pieces. The trolleys moving the work pieces into the kilns and the ceramics kilns itself which have been used for long time and deterioration of the equipment and parts, and the non-complying arrangement of work pieces into the kilns done by the workers, causing crashes and damages.

In this study, the trolleys and the ceramic kilns are renovated and the fixtures are designed to enable the workers to rearrange the work pieces properly. In the future, plant design can be applied to improve the performance procedures for each unit of works. Tools are designed to facilitate the performance in easier and more convenient way.

\section{Acknowledgements}

The authors would like to thank the Ceramics Factory that supported the information and implementing this research.

\section{References}

[1] Mast, J. D., and Lokkerbol, J. 2012. "An Analysis of the Six Sigma DMAIC Method from the Perspective of Problem Solving." International Journal of Production $\begin{array}{llll}\text { Economics } & 139 & \text { (2): } & 604-614 .\end{array}$ doi:10.1016/j.ijpe.2012.05.035.

[2] Magar, V. M., and Shinde, V. B. 2014. "Application of 7 Quality Control (7 QC) Tools for Continuous Improvement of Manufacturing Processes." International Journal of Engineering Research and General Science 2 (4): 364-371.

[3] Dale, H. B. 2003. Quality Control 7th Edition. New Jersey: Prentice Hall.

[4] Sokovic, M., Pavletic, D., and Pipan, K. K. 2010. "Quality Improvement Methodologies-PDCA Cycle, RADAR Matrix, DMAIC and DFSS." Journal of Achievements in Materials and Manufacturing Engineering 33 (1): 476-481.

[5] Chase, R. B., and Aquilano, N. J. 1995. Production and Operations Management: Manufacturing and Services, 7th Edition. Chicago: Irwin.

[6] Juran, J. M. 1974. Quality Control Handbook. New York: McGraw Hill.

[7] Pyzdek, T. 2003. Quality Engineering Handbook, Second 
Edition. New York: Marcel Dekker, Inc..

[8] Pawar, G. J., Sirdeshpande, N. S., Atram, A. B., and Patil, P. R. 2014. "Reduction in Setup Change Time of a Machine in a Bearing Manufacturing Plant Using SMED and ECRS." International Journal of Engineering Research 3 (5): 321-323.
[9] Womack, J. P., and Jones, D. T. 2003. Lean Thinking, 2nd Edition. New York: Simon \& Schuster, Inc..

[10] Ongkunaruk, P., and Wongsatit, W. 2014. "An ECRS-Based Line Balancing Concept: A Case Study of a Frozen Chicken Producer." Business Process Management Journal 20 (5): 678-692. 